\title{
TRANSFER OF ZONA-FREE MOUSE EGGS TO UTERINE FOSTER MOTHERS
}

\author{
ANNE McLAREN \\ Agricultural Research Council Unit of Animal Genetics, Edinburgh
}

(Received 11th December 1968)

\begin{abstract}
Summary. When blastocysts from pregnant mice $3 \frac{1}{2}$ days p.c. were transferred to the uteri of synchronous pseudopregnant recipients, the time of onset of implantation (judged by the appearance of pontamine blue reactivity in the uterus) was not altered by removal of the zona pellucida. The competence of zona-free blastocysts to elicit the pontamine blue reaction was similar to that of control blastocysts. The low implantation rate of eight-cell embryos from donors $2 \frac{1}{2}$ days p.c., transferred to recipients $3 \frac{1}{2}$ days $p . c$., was not increased by previous removal of the zona. It was concluded that, in mice, the decidualizing stimulus from the blastocyst to the uterus stems neither from the zona itself, nor from cellular contact between the vitelline surface and the uterine epithelium.

Removal of the zona by treatment with pronase reduced the viability of transferred blastocysts, so that by mid-gestation the proportion of zona-free blastocysts represented by live embryos was significantly below the control level.
\end{abstract}

\section{INTRODUCTION}

The zona pellucida is not necessary for the normal development of mouse embryos after the eight-cell stage. This is shown by experiments in which the zona is removed mechanically (Tarkowski, 1961) or with the enzyme pronase (Mintz, 1965), and the naked eight-cell embryos fused together and subsequently re-implanted into pseudopregnant females.

No published information exists, however, as to whether removal of the zona reduces (or perhaps increases) the capacity of an embryo to induce a decidual reaction in the host uterus, and to develop normally thereafter. It is only known that some develop normally. The present experiment was designed to test this point, and also to investigate whether removal of the zona would improve the chances of survival of embryos transferred from donors $2 \frac{1}{2}$ days post coitum (p.c.) to recipients $3 \frac{1}{2}$ days p.c. The very low percentage of successful development in such transfers (McLaren \& Michie, 1956) might be due to failure of the young embryos to lose the zona in time to stimulate the uterus during its sensitive period. 


\section{MATERIAL AND METHODS}

The mice used were from the randomly bred $Q$ strain. Eggs were recovered in phosphate-buffered saline at $2 \frac{1}{2}$ days p.c. from the uterine end of the oviduct, or at $3 \frac{1}{2}$ days p.c. from the uterus, and were transferred, in $10 \%$ calf serum in phosphate-buffered saline, to the right uterine horn of recipient females mated to vasectomized males, $2 \frac{1}{2}$ or $3 \frac{1}{2}$ days p.c. Pronase (Galbiochem) was used at a $0.5 \%$ concentration in the same serum-saline mixture. Eggs were left in the pronase solution at room temperature until the zonae disappeared (usually 5 to $10 \mathrm{~min}$ ) and then immediately removed and washed in fresh medium. Recipient females were killed either 4 to 6 days p.c., when implantation was assessed by the pontamine blue reaction, or $10 \frac{1}{2}$ days p.c., at which time implants could be classified into successful (live embryos) and unsuccessful (decidua only). Pontamine blue $(0.2 \mathrm{ml}$ of a $0.5 \%$ solution, Gurr's $5 \mathrm{BX})$ was injected intravenously, $15 \mathrm{~min}$ before killing, and the blue areas along the uterus counted, both in the fresh specimens and after clearing (Orsini, 1962).

In order to allow for the very large variation between recipient females, and for the varying numbers of eggs transferred, the percentage of eggs represented by implantation sites in each female was subjected to angular transformation, and weighted by the number of eggs transferred. Analyses of variance were then carried out and the significance of differences between groups assessed relative to the variation within groups.

All the transfer operations were carried out during the same 5-month period, and eggs from a single donor were often divided between two treatments (e.g. zona intact and zona removed). Analysis of variance revealed no significant heterogeneity among occasions or among individual donors.

\section{RESULTS}

When blastocysts from donors $3 \frac{1}{2}$ days $p . c$. were transferred to recipient females, also $3 \frac{1}{2}$ days p.c., the proportion of females showing evidence of implantation was unaffected by removal of the zona before transfer (Table 1 ). If the pronasetreated and control groups are combined, the proportion of females with pontamine blue areas at $4,4 \frac{1}{3}$ and $4 \frac{2}{3}$ days p.c. (assuming coitus at 01.00 hours) is $17 \%, 53 \%$ and $74 \%$, respectively. This regression $\left(\chi_{(1)}^{2}=7 \cdot 32, P<0.01\right)$ is not unexpected, as we know that implantation is proceeding throughout the 5 th day. In those females showing evidence of implantation, the proportion of transferred eggs represented by blue areas is not significantly greater at $4 \frac{2}{3}$ than at $4 \frac{1}{3}$ days $(48 \%$ versus $40 \%)$, nor does it differ significantly between the pronase-treated and control groups at any time on the 5 th day.

By $10 \frac{1}{2}$ days p.c., however, the situation is different (Table 2). The proportion of recipients showing evidence of implantation did not differ between $4 \frac{2}{3}$ and $10 \frac{1}{2}$ days, nor was it affected at either time by the removal of the zona from the eggs transferred; only those females showing evidence of implantation need therefore be considered. In such females, the proportion of transferred eggs represented by blue areas is significantly higher at $10 \frac{1}{2}$ days than at $4 \frac{2}{3}$ days when the zona is intact $\left(f_{(1,17)}=9.4, P<0.01\right)$, and lower, but not signifi- 
TABLE 1

IMPLANTATION IN FEMALES RECEIVING EGGS WITH AND WITHOUT ZONAE

\begin{tabular}{|c|c|c|c|c|c|c|c|c|}
\hline $\begin{array}{c}\text { Time of } \\
\text { autopsy on } \\
\text { recipient } \\
\text { (days p.c.) }\end{array}$ & Zona & $\begin{array}{c}\text { No. of } \\
\text { recipients }\end{array}$ & $\begin{array}{l}\text { No. } \\
\text { showing } \\
\text { blue } \\
\text { areas }\end{array}$ & $\begin{array}{l}\% \text { of } \\
\text { females } \\
\text { showing } \\
\text { blue } \\
\text { areas }\end{array}$ & $\begin{array}{l}\text { No. of eggs } \\
\text { transferred }\end{array}$ & $\begin{array}{l}\text { No. of eggs } \\
\text { transferred } \\
\text { to females } \\
\text { showing blue } \\
\quad \text { areas }\end{array}$ & $\begin{array}{l}\text { No. of } \\
\text { blue } \\
\text { areas }\end{array}$ & $\begin{array}{c}\text { Blue areas } \\
\text { as } \% \text { of } \\
\text { eggs } \\
\text { transferred* }\end{array}$ \\
\hline 4 & $\begin{array}{l}\text { Intact } \\
\text { Removed }\end{array}$ & $\begin{array}{l}3 \\
3\end{array}$ & $\begin{array}{l}0 \\
1\end{array}$ & $16 \cdot 7$ & $\begin{array}{l}16 \\
17\end{array}$ & $\begin{array}{l}0 \\
6\end{array}$ & $\begin{array}{l}0 \\
1\end{array}$ & $\overline{16 \cdot 7}$ \\
\hline $4 \frac{1}{3}$ & $\begin{array}{l}\text { Intact } \\
\text { Removed }\end{array}$ & $\begin{array}{l}32 \\
32\end{array}$ & $\begin{array}{l}18 \\
16\end{array}$ & $53 \cdot 1$ & $\begin{array}{l}216 \\
224\end{array}$ & $\begin{array}{l}125 \\
131\end{array}$ & $\begin{array}{l}48 \\
55\end{array}$ & $\begin{array}{l}38 \cdot 4 \\
42 \cdot 0\end{array}$ \\
\hline $4 \frac{2}{3}$ & $\begin{array}{l}\text { Intact } \\
\text { Removed }\end{array}$ & $\begin{array}{l}16 \\
11\end{array}$ & $\begin{array}{r}13 \\
7\end{array}$ & $74 \cdot 1$ & $\begin{array}{r}187 \\
76\end{array}$ & $\begin{array}{r}123 \\
50\end{array}$ & $\begin{array}{l}61 \\
22\end{array}$ & $\begin{array}{l}49 \cdot 6 \\
44 \cdot 0\end{array}$ \\
\hline
\end{tabular}

* Only eggs transferred to females showing blue areas have been taken into account in calculating this percentage.

TABLE 2

POST-IMPLANTATIONAL DEVELOPMENT IN FEMALES REGEIVING EGGS WITH AND WITHOUT ZONAE

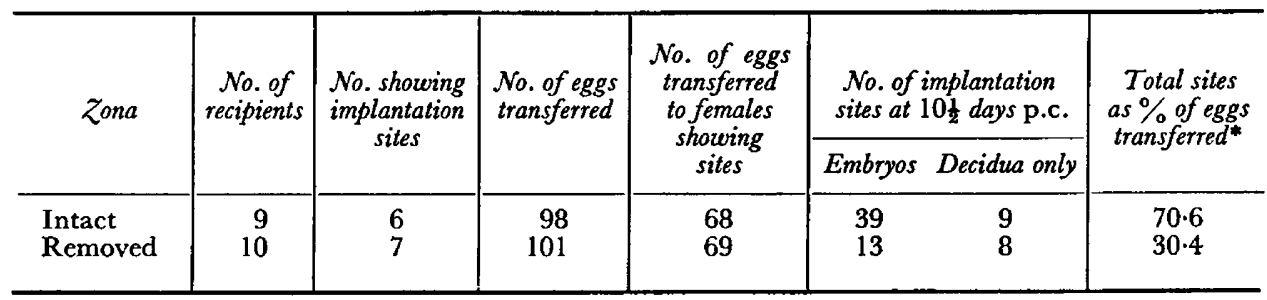

* Only eggs transferred to females showing sites have been taken into account in calculating this percentage.

TABLE 3

DECIDUAL RESPONSE WHEN EGGS WITH AND WITHOUT ZONAE WERE TRANSFERRED FROM DONOR FEMALES $2 \frac{1}{2}$ DAYS P.C. TO RECIPIENTS $3 \frac{1}{2}$ DAYS P.C.

\begin{tabular}{c|c|c|c|c|c|c|c}
\hline $\begin{array}{c}\text { Time of } \\
\text { autopsy } \\
\text { (days p.c.) }\end{array}$ & Zona & $\begin{array}{c}\text { No. of } \\
\text { recipients }\end{array}$ & $\begin{array}{c}\text { No. } \\
\text { showing } \\
\text { blue areas }\end{array}$ & $\begin{array}{c}\text { No. of eggs } \\
\text { transferred }\end{array}$ & $\begin{array}{c}\text { No. of eggs } \\
\text { transferred } \\
\text { to females } \\
\text { showing } \\
\text { blue areas }\end{array}$ & $\begin{array}{c}\text { No. of } \\
\text { blue areas }\end{array}$ & $\begin{array}{c}\text { Blue areas } \\
\text { as \%o of } \\
\text { eggs } \\
\text { transferred }\end{array}$ \\
\hline $4 \frac{2}{3}$ & Intact & 19 & 4 & 149 & 43 & 7 & $4 \cdot 1$ \\
$5 \frac{1}{3}$ & Intact & 5 & 1 & 47 & 8 & 1 & \\
\hline $4 \frac{2}{3}$ & Removed & 19 & 6 & 170 & 56 & $9+10^{*}$ & $4 \cdot 6$ \\
$5 \frac{3}{3}$ & Removed & 6 & 2 & 58 & 19 & 2 & 2 \\
\hline 5
\end{tabular}

* One female, which had received seven eggs, contained ten blue areas. Histological examination revealed that these did not contain eggs, and were probably the result of infection. This female has been omitted from the calculation of $\%$ eggs transferred represented by blue areas. 
cantly so, when the zona is removed. At $10 \frac{1}{2}$ days the effect of removing the zona on the proportion of transferred eggs represented by implantation sites is significant $\left(f_{(1,11)}=6.7, P<0.05\right)$. The reduction in total number of implantation sites in the pronase-treated group is associated with an increase in the proportion of sites occupied only by decidua (i.e. 'moles').

When eggs were transferred from $2 \frac{1}{2}$-day donors to $3 \frac{1}{2}$-day recipients, less than $5 \%$ were represented by pontamine blue areas on the following day (Table 3 ). This percentage was not significantly affected by removal of the zona before transfer, nor by leaving the females for a further $24 \mathrm{hr}$ before autopsy. The proportion of transferred eggs represented by implantation sites at $10 \frac{1}{2}$ days p.c. (Table 4 ) was not significantly higher, and again was unaffected by removal of the zona before transfer. No live embryos were found at $10 \frac{1}{2}$ days p.c. in either the control or pronase-treated group.

TABLE 4

POST-IMPLANTATIONAL DEVELOPMENT WHEN EGGS WITH OR WITHOUT ZONAE WERE TRANSFERRED TO REGIPIENTS $3 \frac{1}{2}$ DAYS P.C.

\begin{tabular}{|c|c|c|c|c|c|c|c|}
\hline \multirow[t]{2}{*}{ Zona } & \multirow[t]{2}{*}{$\begin{array}{c}\text { No. of } \\
\text { recipients }\end{array}$} & \multirow{2}{*}{$\begin{array}{l}\text { No. showing } \\
\text { implantation } \\
\text { sites }\end{array}$} & \multirow[t]{2}{*}{$\begin{array}{l}\text { No. of eggs } \\
\text { transferred }\end{array}$} & \multirow{2}{*}{$\begin{array}{c}\text { No. of eggs } \\
\text { transferred } \\
\text { to females } \\
\text { showing } \\
\text { sites }\end{array}$} & \multicolumn{2}{|c|}{$\begin{array}{l}\text { No. of implantation } \\
\text { sites at } 10 \frac{1}{2} \text { days p.c. }\end{array}$} & \multirow{2}{*}{$\begin{array}{c}\text { Total sites } \\
\text { as \% of eggs } \\
\text { transferred }\end{array}$} \\
\hline & & & & & Embryos & Decidua only & \\
\hline $\begin{array}{l}\text { Intact } \\
\text { Removed }\end{array}$ & $\begin{array}{l}16 \\
16\end{array}$ & $\begin{array}{l}6 \\
8\end{array}$ & $\begin{array}{l}140 \\
142\end{array}$ & $\begin{array}{l}60 \\
67\end{array}$ & $\begin{array}{l}0 \\
0\end{array}$ & $\stackrel{8}{9+10^{*}}$ & $\begin{array}{l}5 \cdot 7 \\
6 \cdot 9\end{array}$ \\
\hline
\end{tabular}

* One female, which had received eleven eggs, contained ten decidua. Since no other female in this series contained more than two decidua, this female was considered to be abnormal (see footnote to Table 3 ) and was omitted from the calculation of $\%$ eggs transferred represented by sites.

\section{DISGUSSION}

In an earlier series (McLaren \& Michie, 1956), blastocysts transferred from donors $3 \frac{1}{2}$ days p.c. to recipients $3 \frac{1}{2}$ days p.c. gave a success rate (in terms of live embryos/eggs transferred) of $10 \%$, or $23 \%$ if only those females in which some transferred eggs developed are included. The corresponding percentages in the present control series (recipient females killed $10 \frac{1}{2}$ days p.c.) are $40 \%$ and $57 \%$. It is impossible to identify the reasons for the greatly improved success rate. Factors which could be responsible, listed in decreasing order of likelihood, are as follows:

1. $10 \%$ calf serum in phosphate-buffered saline as a transfer medium, rather than Pannett-Compton's saline;

2. Finer transfer pipettes (about $100 \mu$ in internal diameter), which do less damage to the uterus and contain a smaller amount of fluid;

3 . Holding the reproductive tract steady by means of a forceps across the oviduct, rather than by grasping the uterine mesentery;

4. Pseudopregnant rather than pregnant recipients;

5. Increased manual dexterity;

6. A different strain of mice ( $Q$ versus TO strain).

The results of the control transfers showed that the number of pontamine 
blue areas, even when counted on the afternoon of the 5 th day ( $4 \frac{2}{3}$ days p.c.), underestimated the number of eggs undergoing implantation. This could be either because a single blue area may contain more than one implanting blastocyst, or because some blastocysts had not yet elicited a pontamine blue reaction at that time.

It is not yet known what properties of a mouse blastocyst elicit the series of uterine changes, of which the earliest yet demonstrated is the pontamine blue reaction (Finn \& McLaren, 1967). One possibility which can be eliminated by the present work is the chemical stimulus of the mucoprotein zona material. It is clear that, during the 5th day of gestation, blastocysts transferred with or without a zona pellucida stimulated pontamine blue reactivity in the uterus at the same time and to the same degree (Table 1). The zona cannot therefore be responsible for eliciting the pontamine blue reaction. Equally, it is unlikely to be the loss of the zona, and the consequent close contact between the vitelline surface and the uterine epithelium, which constitutes the inducing stimulus, since if this were so one might have expected the zona-free blastocysts to stimulate pontamine blue reactivity earlier than did the controls. This conclusion is in agreement with the finding (McLaren, 1969a) that blastocysts with essentially intact zonae can occasionally elicit a pontamine blue reaction.

If loss of the zona is not a necessary condition for stimulating the decidual reaction, the low success rate of embryos recovered from donors $2 \frac{1}{2}$ days p.c. and transferred to the uteri of pregnant or pseudopregnant recipients $3 \frac{1}{2}$ days p.c. (McLaren \& Michie, 1956) is hardly likely to be due to failure of the younger embryos to shed the zona. This is confirmed by the data of Tables 3 and $4:$ the very low proportion of pontamine blue areas in such transfers was not significantly increased by previous removal of the zonae, even if the recipient females were left for an additional day to allow further maturation of the embryos. Indeed, the mean number of blue areas in the uteri receiving $2 \frac{1}{2}$-day embryos was little higher than in those receiving transfer medium alone, or non-deciduomogenic beads, where the areas were all 'empty' and hence presumably due to the trauma of operation (McLaren, 1968). Preliminary histological examination has shown that, while many of the transferred $2 \frac{1}{2}$-day embryos wholly or partially disintegrate, some remain intact but are not associated with any uterine reaction (see McLaren, 1969b, Plate 6).

Although zona-free $3 \frac{1}{2}$-day blastocysts proved competent to elicit a pontamine blue reaction within $24 \mathrm{hr}$ of transfer, there is no doubt that their viability was impaired by the pronase treatment (Table 2). We have found a similar deleterious effect of pronase treatment at the eight-cell stage on subsequent development of mouse embryos in vitro (Bowman \& McLaren, unpublished). Suggestions for minimizing the harmful consequences may be found in two recent publications: Mintz (1967) recommends incubation and dialysis of the pronase solution before use, while Mystkowska \& Tarkowski (1968) mention that they treat mouse embryos with the enzyme only for long enough to thin the zona, removal of the zona being completed mechanically with a pipette.

\section{ACKNOWLEDGMENT}

I gratefully acknowledge financial support from the Ford Foundation. 


\section{REFERENGES}

FinN, C. A. \& McLaren, A. (1967) A study of the early stages of implantation in mice. F. Reprod. Fert. $13,259$.

Mclaren, A. (1968) Can beads stimulate a decidual response in the mouse uterus? F. Reprod. Fert. 15, 313.

McLaren, A. (1969a) Can mouse blastocysts stimulate a uterine response before losing the zona pellucida? F. Reprod. Fert. 19, 199.

Malaren, A. (1969b) Early embryo-endometrial relationships. 2nd Int. Semin. Repr. Physiol. Sex. Endocr., Brussels. Karger, Basle. (In press).

MaLaren, A. \& Mrchie, D. (1956) Studies on the transfer of fertilized mouse eggs to uterine fostermothers. I. Factors affecting the implantation and survival of native and transferred eggs. 7. exp. Biol. 33, 394.

Mrstz, B. (1965) Genetic mosaicism in adult mice of quadriparental lineage. Science, N.X. 148, 1232.

MinTz, B. (1967) Mammalian embryo culture. In: Methods in Developmental Biology. Eds. Wilt and Wessells. Gromwell, New York.

Mystkowska, E. T. \& Tarkowski, A. K. (1968) Observations on CBA-p/CBA-T6T6 mouse chimeras. F. Embryol. exp. Morph. 20, 33.

Orsins, M. W. (1962) Technique of preparation, study and photography of benzyl-benzoate cleared material for embryological studies. F. Reprod. Fert. 3, 283.

TARkowski, A. K. (1961) Mouse chimaeras developed from fused eggs. Nature, Lond. 190, 857. 